\title{
Effect of mutations on the sensitivity of human beta-cell glucokinase to liver regulatory protein
}

\author{
M. Veiga-da-Cunha ${ }^{1}$, L.Z.Xu' ${ }^{2}$, Y.-H.Lee ${ }^{2}$, D.Marotta ${ }^{2}$, S.J.Pilkis ${ }^{2 *}$, E. Van Schaftingen ${ }^{1}$ \\ ${ }^{1}$ Laboratory of Physiological Chemistry, Institute of Cellular and Molecular Pathology and Université Catholique de Louvain, \\ Brussels, Belgium \\ ${ }^{2}$ Department of Biochemistry, Medical School, University of Minnesota, Minneapolis, Minnesota, USA
}

\begin{abstract}
Summary Human beta-cell glucokinase and its liver counterpart displayed a half-saturating concentration of glucose $\left(\mathrm{S}_{0.5}\right)$ of about $8 \mathrm{mmol} / \mathrm{l}$ and a Hill coefficient of 1.7 , and were as sensitive to inhibition by the rat liver regulatory protein as the rat liver enzyme. These results indicate that the $\mathrm{N}$-terminal region of glucokinase, which differs among these three enzymes, is not implicated in the recognition of the regulatory protein. They also suggest that the regulatory protein, or a related protein, could modulate the affinity of glucokinase for glucose in beta cells. We have also tested the effect of several mutations, many of which are implicated in maturity onset diabetes of the young. The mutations affected the affinity for glucose and for the regulatory protein to different degrees, indicating that the binding site for these molecules is different. An Asp ${ }^{158}$ Ala mutation, found
\end{abstract}

in the expression plasmid previously thought to encode the wild-type enzyme, increased the affinity for glucose by about 2.5 -fold without changing the affinity for the regulatory protein. The mutations that were found to decrease the affinity for the regulatory protein (Asn ${ }^{166} \mathrm{Arg}$, Val ${ }^{203} \mathrm{Ala}$, Asn ${ }^{204} \mathrm{Gln}$, Lys ${ }^{414} \mathrm{Ala}$ ) clustered in the hinge region of glucokinase and nearby in the large and small domains. These results are in agreement with the concept that part of the binding site for the regulatory protein is situated in the hinge region of this enzyme. [Diabetologia (1996) 39: 1173-1179]

Keywords Glucokinase, hexokinase, glucokinase regulatory protein, MODY, non-insulin-dependent diabetes mellitus.
Mammalian liver contains a protein inhibitor of glucokinase, which acts competitively with respect to glucose [1-2]. The effect of this regulatory protein is enhanced by fructose 6-phosphate and counteracted by fructose 1-phosphate, both of which act by binding to the inhibitor protein [3]. The regulatory protein inhibits glucokinase by forming a complex with this enzyme; kinetic experiments have suggested that glucokinase has distinct binding sites for the regulatory protein and the substrate analogue $\mathrm{N}$-acetylglucosamine [4].

Received: 4 August 1995 and in revised form: 15 May 1996

* Deceased

Corresponding author: Dr. E. Van Schaftingen, UCL 7539, Avenue Hippocrate 75, B-1200 Brussels, Belgium

Abbreviations: $\mathrm{S}_{0.5}$, Half-saturating concentration of substrate; MODY, maturity onset diabetes of the young; PCR, polymerase chain reaction.
The regulatory protein is specific for glucokinase; it is found in the livers of species that express glucokinase and is absent in species in which glucokinase is absent [5]. Its presence in islets is inferred from the observations that glucokinase activity in islet homogenates is slightly increased by fructose 1phosphate and that islet homogenates inhibit rat liver glucokinase in a fructose 1-phosphate-sensitive manner [6]. Direct demonstration of the presence of the regulatory protein in islet tissue is, however, still lacking. Glucokinase partially purified from islet extracts is sensitive to the rat liver regulatory protein, but the paucity of the enzyme does not permit a detailed kinetic analysis of the effect of the regulatory protein on islet glucokinase [6]. Betacell glucokinase differs from its liver counterpart [7] by the first 15 amino acids encoded by exon 1 or 1 ' [8]. 
The availability of recombinant human beta-cell glucokinase [9] has made it possible to study more carefully the kinetic effects of rat liver regulatory protein. In this report, we have also investigated the sensitivity of various glucokinase mutants, some of which are found in maturity onset diabetes of the young (MODY) [9-13], to the regulatory protein to ascertain whether these mutations alter the affinity for glucose to the same extent as the affinity for the regulatory protein. While this work was in progress, it was found that the recombinant clone from which the expression vectors for human islet and human liver glucokinases were derived contained a mutation replacing $\mathrm{Asp}^{158}[14,15]$ by an alanine residue. We have also investigated the effect of this mutation.

\section{Materials and methods}

The regulatory protein was purified from rat liver up to the hydroxylapatite step [16] and was freed of inorganic phosphate by gel filtration on Sephadex G-25. Rat liver glucokinase was purified from livers as described previously [9]. The preparation of recombinant forms of human liver and human betacell glucokinase (which are actually $A s p^{158}$ Ala mutants), and of the site-directed mutants of the latter enzyme was reported previously [9-12]. It should be noted that the construction of the Asn ${ }^{166}$ Arg mutant led to the reversion of Ala ${ }^{158}$ to an Asp residue. The true wild-type enzymes were prepared by "repairing" the Ala ${ }^{158}$ mutation according to the following site-directed mutagenesis procedure. The $5^{\prime}$ (up to nucleotide 480) and the $3^{\prime}$ (from nucleotide 481) coding regions of the human beta-cell glucokinase cDNA inserted in pBlueScript $\mathrm{KS}+$ (pBS-HIGKAsp ${ }^{158} \mathrm{Ala}$ ) were amplified in two separate PCR reactions with Pwo DNA polymerase using as primers $T 7$ and $5^{\prime}$ - ATCGATATCTTCGTGCCTCAC - 3', for the 5' region and $\mathrm{T} 3$ and $5^{\prime}-\mathrm{AAGGGCATCCTTCTCAACTGG}-3^{\prime}$, for the $3^{\prime}$ region. The glucokinase-specific primers (mismatches underlined) were phosphorylated at their $5^{\prime}$-ends. The amplified fragments (560 and 1355 base pairs [bp]) were restricted with $X b a \mathrm{I}$ and $B a m \mathrm{HI}$, respectively, and purified by agarose gel electrophoresis. They were then simultaneously ligated in pBS that had been restricted with both $X b a \mathrm{I}$ and Bam HI, and the resulting construct was used to transform Escherichia coli JM 109. The glucokinase insert was checked by sequencing to exclude polymerase chain reaction (PCR) errors. The expression vector for human wild-type beta-cell glucokinase (pET-HIGKAla ${ }^{158} \mathrm{Asp}$ ) was then constructed by replacing a Sac II-Sac I fragment in the expression vector coding for human beta-cell glucokinase Asp ${ }^{158}$ Ala by the corresponding "repaired" fragment. The expression vector for human wild-type liver glucokinase (pET-HLGKAla ${ }^{158} \mathrm{Asp}$ ) was similarly constructed. These "repaired" cDNAs were subsequently used to transform E. coli BL21(DE3) pLysS [17] and the recombinant proteins were expressed and purified as described [18].

Glucokinase was assayed spectrophotometrically at $30^{\circ} \mathrm{C}$ in a mixture containing, except where otherwise indicated, $25 \mathrm{mmol} / 1 \mathrm{Hepes}, \mathrm{pH} 7.1,5 \mathrm{mmol} / 1$ glucose, $1 \mathrm{mmol} / 1 \mathrm{ATP}$, $1 \mathrm{mmol} / 1 \mathrm{MgCl}_{2}, 1 \mathrm{mmol} / 1$ dithiothreitol, $200 \mu \mathrm{mol} / 1$ fructose 6-phosphate, $25 \mathrm{mmol} / \mathrm{K} \mathrm{KCl}, 0.25 \mathrm{mmol} / \mathrm{l}$ phosphoenolpyruvate, $0.15 \mathrm{mmol} / 1 \mathrm{NADH}, 10 \mu \mathrm{g} / \mathrm{ml}$ of rabbit muscle lactate dehydrogenase and of pyruvate kinase (desalted by gel filtration). For the determination of the affinity of glucokinase for the regulatory protein, care was taken to use low concentrations

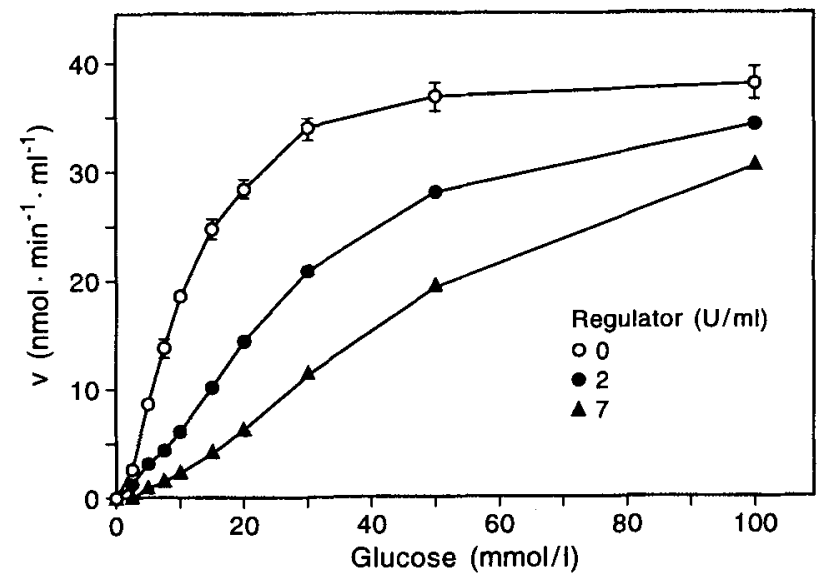

Fig.1. Effect of different concentrations of rat liver regulatory protein on the glucose saturation curve of wild type recombinant human islet glucokinase

of glucokinase $(<160 \mu \mathrm{g} / 1)$ to avoid overestimation of the true affinity constants [16]. For the analysis of glucose saturation curves, the $V_{\max }$ was estimated on Hanes plots from values observed at high concentrations of substrate (typically 50 $300 \mathrm{mmol} / \mathrm{l}$ ) and $\mathrm{S}_{0.5}$ values on Hill plots.

\section{Results}

Effect of the regulatory protein on the kinetics of the wild-type enzyme. For the kinetic studies, glucokinase was assayed at $\mathrm{pH} 7.1$ and in the presence of $25 \mathrm{mmol} / \mathrm{K} \mathrm{KCl}$. These conditions are optimal to study the effect of the regulatory protein because a higher $\mathrm{pH}$ or higher concentration of $\mathrm{Cl}^{-}$would antagonize its effect [4]. Figure 1 shows that, as for rat liver glucokinase, the glucose saturation curve of the wildtype human beta-cell glucokinase was sigmoidal, displaying under our assay conditions a $S_{0.5}$ of approximately $8 \mathrm{mmol} / \mathrm{l}$ and a Hill coefficient close to 1.7 .

Figure 1 also shows that rat liver regulatory protein caused an increase in the $\mathrm{S}_{0.5}$ value without changing $V_{\max }$, i.e., that the regulatory protein behaved as a competitive inhibitor. Plots of $1 / \mathrm{v}$ as a function of the concentration of inhibitor at different concentrations of glucose were linear and their extrapolations crossed at a value of about $-0.8 \mathrm{U}$ of regulatory protein/ml (Fig. 2). Based on these results, it was concluded that the competitive inhibition constant of beta-cell glucokinase was $0.8 \mathrm{U}$ regulatory protein $/ \mathrm{ml}$, i. e. $4 \mathrm{nmol} / \mathrm{l}[16]$. A similar value was obtained with rat liver glucokinase (results not shown).

As previously reported for rat liver glucokinase [1], the inhibition exerted by the regulatory protein was modulated by fructose 6-phosphate, which increased the inhibition, and by fructose 1-phosphate which antagonized the inhibition (data not shown). Thus, in the presence of $3.2 \mathrm{U}$ of regulatory protein per $\mathrm{ml}$, a half-maximal effect of fructose 6-phosphate was observed at a concentration of about $10 \mu \mathrm{mol} / 1$. At the 


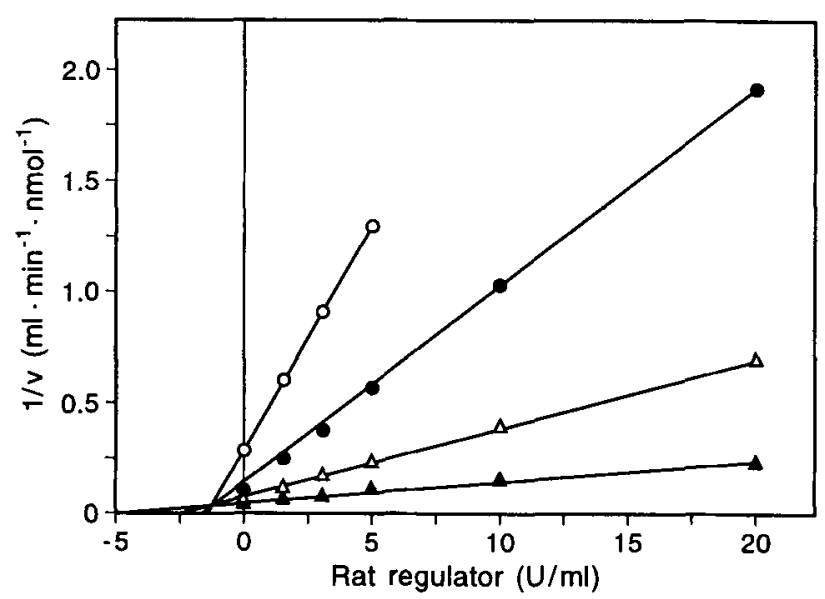

Fig. 2. Dixon plot of the inhibition of wild type human islet glucokinase by the rat liver regulatory protein. The activity was measured in the presence of $3(0), 5(\bullet), 10(\Delta)$ or 20 (A) $\mathrm{mmol} / \mathrm{l}$ glucose

same concentration of regulatory protein and in the presence of $50 \mu \mathrm{mol} / 1$ fructose 6 -phosphate, $20 \mu \mathrm{mol} / 1$ fructose 1-phosphate was needed to release half of the inhibition. $\mathrm{KCl}$ and, to a lesser extent, potassium acetate were found to release the inhibition exerted by the regulatory protein on beta-cell glucokinase (data not shown) with similar sensitivities to those previously observed with rat liver glucokinase [4].

Affinity of glucokinase mutants for glucose and $\mathrm{N}$ acetyl-glucosamine. It was of interest to determine

Fig. 3a,b. Hill plot (a) Hanes plot (b) of the glucose saturation curve of wild type human islet glucokinase. The activity of the human islet glucokinase was determined at different concentrations of glucose under the assay conditions described in Methods. Data are the means of triplicates \pm SEM. In (b), the regressions shown have been calculated for three sets of glucose concentrations in mmol/l: 1) 5 to 20, 2) 7.5 to 30 and 3) 20 to 50 ; the $K_{m}$ s derived from these regressions were 17.9 and $5 \mathrm{mmol} / \mathrm{l}$, respectively

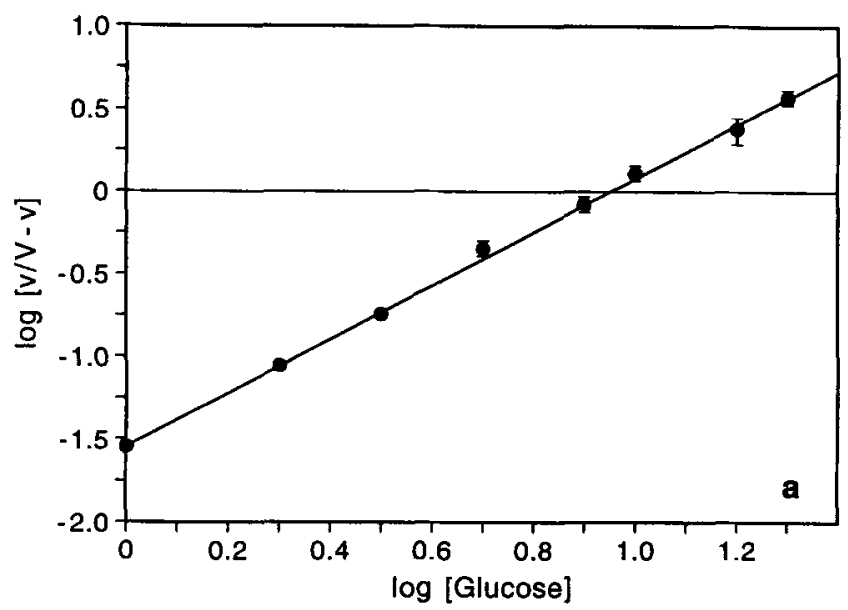

the sensitivity of the various mutant forms of glucokinase to the inhibition exerted by the regulatory protein. Since some of the mutations alter the affinity for glucose and the regulatory protein behaves as a competitive inhibitor, it was important to determine the affinity for the regulatory protein under comparable conditions, i.e. at similar degrees of glucose saturation. The half-saturating concentrations of glucose were determined graphically on Hill plots, as exemplified in Figure 3 a for the wild-type beta-cell enzyme. It is apparent that this type of plot was linear and that it allowed the safe calculation of the half-saturating concentration of substrate $(8 \mathrm{mmol} / \mathrm{l})$ and the Hill coefficient (1.7). Since some authors have analysed glucokinase kinetics by assuming Michaelis-Menten kinetics [9-13], we also show the results as Hanes plots (Fig. 3b). As expected for a sigmoidal enzyme, this type of plot was curvilinear and different $\mathrm{K}_{\mathrm{m}} \mathrm{s}$ (from 5 to $17 \mathrm{mmol} / \mathrm{l}$ in the example) could be calculated depending on the set of data points considered.

Table 1 lists the $S_{0.5}$ values that we observed under our experimental conditions. They differ from the $\mathrm{K}_{\mathrm{m}}$ values reported previously [9-13], but this is most likely due to the fact that the kinetics were previously analysed assuming Michaelis-Menten kinetics. Furthermore, some of the proteins tested in this work and previously [9-12] are actually double-mutants. For the Lys ${ }^{414} \mathrm{Ala}$ and the Lys ${ }^{414} \mathrm{Glu}$ mutants we observed that the inclusion of $25 \mathrm{mmol} / \mathrm{K} \mathrm{KCl}$ in the assay markedly decreased the $S_{0.5}$ value (from 16 to $2.3 \mathrm{mmol} / 1$ and from 22 to $4.2 \mathrm{mmol} / \mathrm{l}$, respectively), whereas no such effect was observed with the wildtype enzymes.

The human beta cell and liver enzymes had the same affinities for glucose, the $S_{0.5}$ values of the nonmutated forms being almost identical to that of rat liver glucokinase $(\sim 8 \mathrm{mmol} / \mathrm{l})$, while the $S_{0.5}$ of the enzymes with the $\mathrm{Asp}^{158}$ Ala mutation was about 2.5 fold lower. An $S_{0.5}$ value of approximately $3.5 \mathrm{mmol} / 1$ was also observed with this mutant under the assay conditions of Lange et al. [19]. The mutant with the lowest affinity for glucose was the

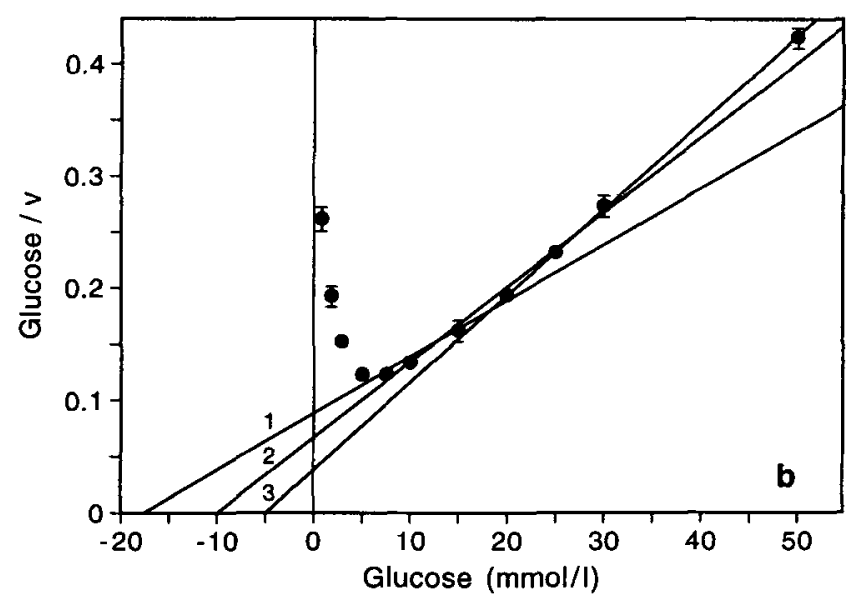


Table 1. Kinetic properties of rat liver glucokinase and of recombinant wild type and mutant forms of human islet and liver glucokinases

\begin{tabular}{|c|c|c|c|c|c|c|}
\hline \multirow[t]{2}{*}{ Glucokinase } & \multirow[t]{2}{*}{$\begin{array}{l}\mathrm{S}_{0.5} \\
(\mathrm{mmol} / \mathrm{l})\end{array}$} & \multirow[t]{2}{*}{$\mathrm{h}$} & \multicolumn{2}{|c|}{$\begin{array}{l}\text { [Regulatory protein] causing } 50 \% \\
\text { inhibition }\end{array}$} & \multirow[t]{2}{*}{$\begin{array}{l}\mathrm{I}_{50} \mathrm{NAG} \\
(\mathrm{mmol} / \mathrm{l})\end{array}$} & \multirow[t]{2}{*}{$\begin{array}{l}\text { [G]ucose] } \\
(\mathrm{mmol} / \mathrm{l})\end{array}$} \\
\hline & & & $\begin{array}{l}\text { at } 5 \mathrm{mmol} / \mathrm{l} \\
\text { glucose }(\mathrm{U} / \mathrm{ml})\end{array}$ & $\begin{array}{l}\text { at indicated } \\
\text { [Glucose] }(\mathrm{U} / \mathrm{ml})\end{array}$ & & \\
\hline Rat liver & 8 & 1.74 & 1 & $2.1 \pm 0.3(4)$ & 0.20 & 8 \\
\hline $\begin{array}{l}\text { Human islet wild type } \\
\text { Human islet } \mathrm{Asp}^{158} \mathrm{Ala}\end{array}$ & $\begin{array}{l}7.6 / 7.8 \\
3.27 \pm 0.15(3)\end{array}$ & $\begin{array}{l}1.75 / 1.7 \\
1.73 \pm 0.03(3)\end{array}$ & $\begin{array}{l}1 / 1(2) \\
5.4 \pm 0.42(3)\end{array}$ & $\begin{array}{l}2.4 / 2.6(2) \\
2.4 / 2.8(2)\end{array}$ & $\begin{array}{l}0.20 \\
0.22\end{array}$ & $\begin{array}{l}8 \\
3.3\end{array}$ \\
\hline $\begin{array}{l}\text { Human liver wild type } \\
\text { Human liver Asp }{ }^{158} \mathrm{Ala}\end{array}$ & $\begin{array}{l}7.8 / 8 \\
3.3 / 3.4\end{array}$ & $\begin{array}{l}1.6 / 1.75 \\
1.75 / 1.6\end{array}$ & $\begin{array}{l}1 / 1.1(2) \\
5.57 \pm 0.03(3)\end{array}$ & $\begin{array}{l}2.4 / 2.5(2) \\
2.4 / 3.0(2)\end{array}$ & $\begin{array}{l}0.20 \\
0.22\end{array}$ & $\begin{array}{l}8 \\
3.3\end{array}$ \\
\hline Asn ${ }^{166} \mathrm{Arg}$ & $2.7 \pm 0.06(3)$ & $1.22 / 1.22$ & $6.53 \pm 0.57(3)$ & $3.92 \pm 0.4(3)$ & 0.25 & 3 \\
\hline $\mathrm{Val}^{182} \mathrm{Met}^{\mathrm{a}}, \mathrm{Asp}^{158} \mathrm{Ala}$ & $20.1 \pm 0.7(3)$ & $1.62 / 1.8$ & $0.67 \pm 0.04(3)$ & $1.57 \pm 0.09(3)$ & 0.40 & 20 \\
\hline $\mathrm{Val}^{203} \mathrm{Ala}^{\mathrm{a}}, \mathrm{Asp}^{158} \mathrm{Ala}$ & $38.5 / 39.5$ & $1.44 / 1.37$ & $30 / 30(2)$ & $31 / 32(2)$ & 0.50 & 40 \\
\hline $\mathrm{Asn}^{204} \mathrm{Gln}, \mathrm{Asp}^{158} \mathrm{Ala}$ & $200 \pm 26(4)$ & $1.06 \pm 0.02$ & n.d. & $24 / 22(2)$ & $>20$ & 200 \\
\hline $\mathrm{Glu}^{279} \mathrm{Gln}^{\mathrm{a}}, \mathrm{Asp}^{158} \mathrm{Ala}$ & $19.3 \pm 0.33(3)$ & $1.34 \pm 0.06(3)$ & $1.89 \pm 0.07(4)$ & $3.13 \pm 0.13(3)$ & 0.60 & 20 \\
\hline Lys ${ }^{414} \mathrm{Ala}, \mathrm{Asp}{ }^{158} \mathrm{Ala}$ & $2.3 \pm 0.17(3)$ & $1.45 \pm 0.01(3)$ & $14 / 15(2)$ & $8.0 / 7.6(2)$ & 0.18 & 2.3 \\
\hline Lys $^{414} \mathrm{Glu}^{\mathrm{a}}, \mathrm{Asp}^{158} \mathrm{Ala}$ & 4.2 & 1.37 & 6.3 & 3.8 & 0.18 & 3 \\
\hline
\end{tabular}

The effect of the regulatory protein was tested at $5 \mathrm{mmol} / \mathrm{glu}$ cose or at the concentration indicated in the last column. This was also the concentration used to estimate the half inhibitory concentration of $\mathrm{N}$-acetylglucosamine $\left(\mathrm{I}_{50} \mathrm{NAG}\right)$. Results are

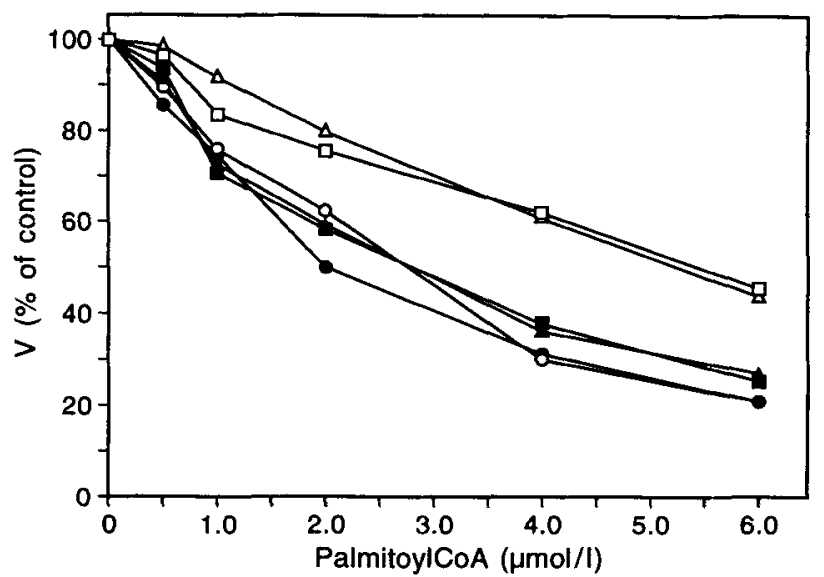

Fig. 4. Effect of palmitoylCoA on the activity of wild type rat liver and human beta-cell glucokinase and of various mutants. The enzymes were assayed at concentrations of glucose close to their $S_{0.5}$ values (Table 1). (O) Rat liver GK; (๑) wild type islet glucokinase; ( $) \mathrm{Asn}^{166} \mathrm{Arg}$; ( $\left.\mathbf{A}\right) \mathrm{Asp}^{158} \mathrm{Ala}, \mathrm{Val}^{203} \mathrm{Ala}$; (口) Asp ${ }^{158} \mathrm{Ala}, \mathrm{Glu}^{279} \mathrm{Gln} ;(\triangle) \mathrm{Asp}^{158} \mathrm{Ala}$, Lys ${ }^{414}$ Ala. All the other glucokinases present in Table 1 but not shown in this figure behaved like the wild type beta-cell glucokinase except the mutant Lys ${ }^{414} \mathrm{Glu}$ which had an intermediate behaviour

$\mathrm{Asn}^{204} \mathrm{Gln}$, which was the only one in this series to display hyperbolic kinetics, as indicated by a Hill coefficient close to 1 . Other mutations (Val ${ }^{182} \mathrm{Met}$, $\mathrm{Val}^{203} \mathrm{Ala}, \mathrm{Glu}^{279} \mathrm{Gln}$ ) had decreased affinities for glucose but without important changes in the sigmoid character of their glucose saturation curves.

The affinity for $\mathrm{N}$-acetylglucosamine was determined by measuring the concentration of the aminosugar required to inhibit glucokinase by $50 \%$ at a individual values or the means \pm SEM for $(n)$ values. The values shown for the inhibition by $\mathrm{N}$-acetylglucosamine were supported by other measurements performed at other glucose concentrations. ${ }^{a}$ Mutations found in subjects with MODY concentration of glucose close to the $\mathrm{S}_{0.5}$ value. For the $\mathrm{Val}^{182} \mathrm{Met}$, the $\mathrm{Val}^{203} \mathrm{Ala}$, the $\mathrm{Asn}^{204} \mathrm{Gln}$ and the Glu ${ }^{279} \mathrm{Gln}$ mutants, the decrease in the affinity for glucose was accompanied by a decrease in the affinity for $\mathrm{N}$-acetylglucosamine. Little change in affinity for this inhibitor was however observed with the other mutants, including the $\mathrm{Asp}^{158}$ Ala proteins.

Affinity of glucokinase mutants for the regulatory protein and for palmitoylCoA. The sensitivity of the wildtype and mutant glucokinases to inhibition by the regulatory protein was determined both at a fixed glucose concentration ( $5 \mathrm{mmol} / \mathrm{l}$ glucose $)$ and at a glucose concentration close to the $S_{0.5}$ value determined under our experimental conditions. The latter is expected to reflect the affinity for the regulatory protein independent of changes in the affinity for glucose. Care was taken to use concentrations of glucokinase lower than the dissociation constant of the glucokinase/regulatory protein complex $\left(3 \times 10^{-9} \mathrm{~mol} / \mathrm{l}\right)$ to avoid overestimation of the inhibition constants [16]. It should be noted that the Asp ${ }^{158}$ Ala mutation did not result in a change in the affinity for the regulatory protein. Four mutations $\left(\mathrm{Asn}^{166} \mathrm{Arg}, \mathrm{Val}^{203} \mathrm{Ala}\right.$, $\mathrm{Asn}^{204} \mathrm{Gln}$, and $\mathrm{Lys}^{414} \mathrm{Ala}$ ) caused a significant decrease ( $>1.5$-fold) in the affinity for the regulatory protein while the $\mathrm{Val}^{182} \mathrm{Met}$ mutation slightly increased this affinity. These changes did not always parallel those in the affinity for glucose or $\mathrm{N}$-acetylglucosamine. Indeed the Val ${ }^{182} \mathrm{Ala}$ mutant, which had a decreased affinity for both glucose and $\mathrm{N}$ acetylglucosamine, showed an increased affinity for the regulatory protein, while the $\mathrm{Lys}^{414} \mathrm{Ala}$ and the 


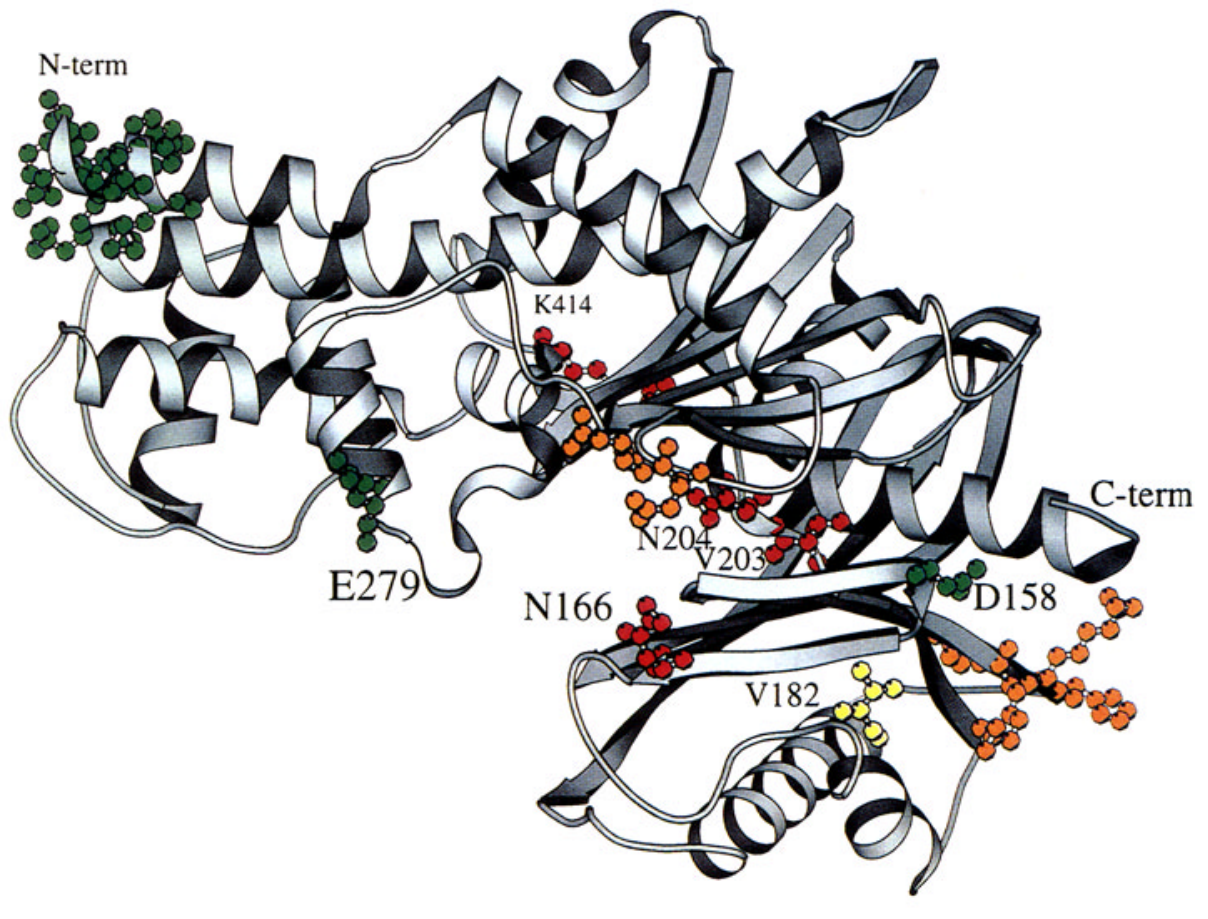

Fig.5. Ribbon drawing of the $\alpha$-carbon backbone of the beta-cell human glucokinase based on the yeast hexokinase structure in the open configuration. All the amino acid mutations studied are indicated. The residues in green correspond to mutations that do not affect the affinity for the regulatory protein. The residues in red and yellow correspond to the mutations that respectively decreased or increased the affinity for the regulatory protein. The residues in orange, $\mathrm{Glu}^{51}$ and $\mathrm{Glu}^{52}$ and the loop $\mathrm{Va}^{154}$ to $\mathrm{Asp}^{158}$, were previously shown [18] to decrease the affinity of glucokinase for the regulatory protein when replaced by corresponding residues in rat hexokinase I. The glucokinase model is represented using the MOLSCRIPT software [29] and the coordinates of Charles et al. [30]
Asn ${ }^{166} \mathrm{Arg}$ mutants had an increased affinity for glucose compared to their respective controls, and a decreased affinity for the regulatory protein.

We have also tested the sensitivity of glucokinase to long chain acylCoAs. All mutants, with two exceptions, displayed a sensitivity to palmitoylCoA that was close, or identical, to that expressed by wildtype human glucokinases, which in turn was the same as that of the rat liver enzyme. As shown in Figure 4 , the Lys $^{414} \mathrm{Ala}$ and the Glu ${ }^{279} \mathrm{Gln}$ mutants displayed $\mathrm{a} \approx 2.5$-fold decrease in the sensitivity to this effector.

\section{Discussion}

The mutation Asp ${ }^{158}$ Ala was found in the expression plasmids used in the present study as well as in the cDNA produced by Nishi and co-workers [14]. It is not known at present if this mutation results from a PCR error (part of the complete cDNA produced by Nishi and co-workers was obtained by amplification with Taq polymerase) or from a cloning artifact. The fact that $\mathrm{Asp}^{158}$ is conserved among glucokinases $[18]$ and that the Ala ${ }^{158}$ variant remained unnoticed until now, despite intensive research of mutations in the glucokinase gene, argues against a polymorphism.

The replacement of this residue by an alanine results in a significant increase in the affinity for glucose. This observation is not surprising since Asp ${ }^{158}$ is situated in the hinge region of glucokinase (Fig.5) close to residues $\mathrm{Val}^{203}$ and $\mathrm{Asn}^{204}$, which, when $\mathrm{mu}$ tated to alanine and glutamine, respectively, lead to enzymes with a very low affinity for glucose [20]
(Table 1). Furthermore it was found recently that the replacement of residues $\mathrm{Va}^{154}$ to $\mathrm{Asp}^{158}$ by the corresponding residues of rat hexokinase I results in a tenfold decrease in the affinity for glucose [18].

The $S_{0.5}$ value of the $A \mathrm{sp}^{158} \mathrm{Ala}$ mutant was consistently found in this work to be about $3.5 \mathrm{mmol} / \mathrm{l}$ while the " $\mathrm{K}_{\mathrm{m}}$ " values mentioned in the literature for the same enzyme (reported to be the wild-type enzyme) range between $8 \pm 2$ and $6 \pm 0.4 \mathrm{mmol} / \mathrm{l}$ [9-12]. This inconsistency is not due to differences in the assay conditions but most likely results from the use of inappropriate methods to calculate $\mathrm{K}_{\mathrm{m}}$ values for glucokinase (the term $\mathrm{K}_{\mathrm{m}}$ is actually meaningless for a sigmoidal enzyme). It is well known that, for enzymes with sigmoidal saturation curve, double-reciprocal plots are curvilinear. The same is true for Hanes plots, though the latter type of plot may give the wrong impression of linearity at elevated concentrations of substrate. It can be demonstrated, however, that for an enzyme responding to the Hill equation, there is no linear portion in a Hanes plot if $h \neq 1$. This is the reason why different $K_{m}$ values are calculated depending on the set of data used (Fig. 3b). In contrast, the use of the Hill plot gives $S_{0.5}$ values which are independent of the chosen data set (Fig. $3 \mathrm{a}$ ). The importance of correctly determining $S_{0.5}$ values of glucokinase has been recently discussed by Cardenas [21].

Previous work performed on xenopus glucokinase indicated that the regulatory protein binds to the tip of the small domain and to the hinge region of this enzyme [18]. Mutations of residues 51 and 52, as well as of residues 141-144 resulted in a remarkable decrease in the affinity for the regulatory protein 
(Fig.5). The results obtained in the present work confirm and extend these conclusions. Thus, the mutations that result in a decrease in the affinity for the regulatory protein cluster in the hinge region $\left(\mathrm{Val}^{203} \mathrm{Ala}, \mathrm{Asn}^{204} \mathrm{Gln}\right)$, in close proximity to $\mathrm{Glu}^{51}$ and $\mathrm{Glu}^{52}$, and in the nearby regions of the small $\left(\mathrm{Asn}{ }^{166} \mathrm{Arg}\right.$ ) and the large domain (Lys ${ }^{414} \mathrm{Ala}$; Fig. 5). The increase in affinity induced by the Val ${ }^{182}$ Met mutation could be due to a change in the positioning of the $\mathrm{His}^{141}-\mathrm{Leu}^{144}$ loop, which appears to play an important role in the binding of the regulatory protein [18]. The fact that the beta-cell enzyme and the liver enzyme have the same affinity for the regulatory protein indicates that the fifteen $\mathrm{N}$-terminal amino acids, which are located in the large domain, are remote from the regulatory protein binding site.

By binding to the hinge region, the regulatory protein is likely to interfere with the closure of the catalytic cleft, which appears to be a prerequisite for the phosphoryl transfer reaction occurring between ATP and glucose in hexokinases.

Until now, only two mutants have been found to have a decreased affinity for palmitoylCoA. Both mutations involve residues ( $\mathrm{Lys}^{414}$ and $\mathrm{Glu}^{279}$ ) that are in the large domain of the enzyme. These results indicate that the binding site for palmitoylCoA is most likely on the "internal" face of the large domain (Fig. 5). The lack of synergism between palmitoyl$\mathrm{CoA}$ and the regulatory protein [16] is probably due to the fact their binding sites partially overlap in the hinge region.

A growing body of evidence indicates that glucokinase plays a critical role in the control of insulin secretion by the beta cell. Insulin secretion correlates with glucose metabolism in beta cells and glucokinase appears to be the rate-limiting enzyme of glycolysis in these cells (reviewed in [22-24]). In addition, mutations of the glucokinase gene that result in the synthesis of inactive enzyme or enzyme with reduced activity lead to a form of non-insulin-dependent diabetes called MODY, which is characterized by a decreased insulin secretion (reviewed in [25-26]). This condition is inherited in an autosomal dominant fashion indicating that a $50 \%$ decrease or even a decrease of smaller magnitude in the activity of glucokinase is sufficient to cause a significant reduction in insulin secretion.

The fact that islet glucokinase is sensitive to the regulatory protein indicates that a similar type of mechanism to that found in liver could operate in islet cells. Equally, since fructose 1-phosphate was found to stimulate the activity of glucokinase in extracts of islets $[6,27]$, this indicates that these cells could contain a regulatory protein that is similar or related to that found in liver. Interestingly, low amounts of regulatory protein mRNA were found in rat islets [27]. However, it remains to be seen if the concentration of regulatory protein is sufficient to exert a significant inhibition in vivo.
Sturis and co-workers [28] have shown that, in several subjects with mutations in the glucokinase gene, insulin secretion was reduced compared to that in control subjects but less than predicted from the calculated decrease in glucokinase flux, suggesting that there are compensatory changes. One possibility is upregulation of the glucokinase expression as a result of the increase in the blood glucose level [26]. The second possibility is a decrease in the inhibitory effect of the regulatory protein. The present work shows that this could be the case for the $\mathrm{Va}^{203} \mathrm{Ala}$ mutant, which has a reduced affinity for the regulatory protein. Patients harbouring this mutation were found to have reduced rates of insulin secretion but this reduction was less than predicted by loss of enzymic activity [26].

Acknowledgements. The authors would like to thank Ms. G. Berghenouse for skillful technical assistance and Dr. J.P.Szikora for help with the molecular computer modelling. This work was supported by the Belgian Fonds National de la Recherche Scientifique, by the Actions de Recherche Concertées, by the Belgian Federal Service for Scientific, Technical and Cultural Affairs, by the National Institutes of Health and by the Juvenile Diabetes Foundation. MVDC is Chargé de Recherches at the Belgian Fonds National de la Recherche Scientifique.

\section{References}

1. Van Schaftingen E (1989) A protein from rat liver confers to glucokinase the property of being antagonistically regulated by fructose 6-phosphate and fructose 1-phosphate. Eur J Biochem 179: 179-184

2. Van Schaftingen E, Detheux M, Veiga-da-Cunha M (1994) Short-term control of glucokinase activity: role of a regulatory protein. FASEB J 8: 414-419

3. Vandercammen A, Detheux M, Van Schaftingen E (1992) Binding of sorbitol 6-phosphate and of fructose 1-phosphate to the regulatory protein of liver glucokinase. Biochem J 286: 253-256

4. Vandercammen A, Van Schaftingen E (1991) Competitive inhibition of liver glucokinase by its regulatory protein. Eur J Biochem 200: 545-551

5. Vandercammen A, Van Schaftingen E (1993) Species and tissue distribution of the regulatory protein of glucokinase. Biochem J 294: 551-556

6. Malaisse WJ, Malaisse-Lagae F, Davies DR, Vandercammen A, Van Schaftingen E (1990) Regulation of glucokinase by a fructose-1-phosphate-sensitive protein in pancreatic islets. Eur J Biochem 190: 539-545

7. Andreone TL, Printz RL, Pilkis SJ, Magnuson MA, Granner DK (1989) The amino acid sequence of rat liver glucokinase deduced from cloned cDNA. J Biol Chem 264: 363-369

8. Magnuson MA, Shelton KD (1989) An alternate promoter in the glucokinase gene is active in the pancreatic $\beta$ cell. J Biol Chem 264: 15936-15942

9. Gidh-Jain M, Takeda J, Xu LZ et al. (1993) Glucokinase mutations associated with non-insulin-dependent (type 2) diabetes mellitus have decreased enzymatic activity: implications for structure/function relationships. Proc Natl Acad Sci USA 90: 1932-1936 
10. Takeda J, Gidh-Jain M, Xu LZ et al. (1993) Structure/function studies of human $\beta$-cell glucokinase. Enzymatic properties of a sequence polymorphism, mutations associated with diabetes and other site-directed mutants. J Biol Chem 268: 15200-15204

11. Xu LZ, Zhang W, Weber IT, Harrison RW, Pilkis SJ (1994) Site-directed mutagenesis studies on the determinants of sugar specificity and cooperative behavior of human $\beta$-cell glucokinase. J Biol Chem 269: 27458-27465

12. Xu LZ, Harrison RW, Weber IT, Pilkis SJ (1995) Human $\beta$ cell glucokinase. Dual role of Ser-151 in catalysis and hexose affinity. J Biol Chem 270: 9939-9946

13. Liang Y, Kesavan P, Wang LQ et al. (1995) Variable effects of maturity-onset-diabetes of youth (MODY)-associated glucokinase mutations on substrate interactions and stability of the enzyme. Biochem J 309: 167-173

14. Nishi S, Stoffel M, Xiang K, Shows TB, Bell GI, Takeda J (1992) Human pancreatic beta-cell glucokinase: cDNA sequence and localization of the polymorphic gene to chromosome 7, band p 13. Diabetologia 35: 743-747

15. Korany LI, Tanizawa Y, Welling CM, Rabin DU, Permutt MA (1992) Human islet glucokinase gene. Diabetes 41: $807-811$

16. Vandercammen A, Van Schaftingen E (1990) The mechanism by which rat liver glucokinase is inhibited by the regulatory protein. Eur J Biochem 191: 483-489

17. Studier FW, Moffat BA (1986) Use of bacteriophage T7 RNA polymerase to direct selective high-level expression of cloned genes. J Mol Biol 189: 113-130

18. Veiga-da-Cunha M, Courtois S, Michel A, Gosselain E, Van Schaftingen E (1996) Amino acid conservation in animal glucokinases. Identification of the residues implicated in the interaction with the regulatory protein. J Biol Chem 271: 6292-6297

19. Lange AJ, Xu LZ, Van Poelwijk F, Lin K, Granner DK, Pilkis SJ (1991) Expression and site-directed mutagenesis of hepatic glucokinase. Biochem J 277: 159-163
20. Pilkis SJ, Weber IT, Harrison RW, Bell GI (1994) Glucokinase: structural analysis of a protein involved in susceptibility to diabetes. J Biol Chem 35: 21925-21928

21. Cardenas ML (1995) Kinetic and structural properties of hepatic hexokinase $\mathrm{D}$, a monomeric cooperative enzyme. Glucokinase: its regulation and role in liver metabolism. Springer-Verlag, Heidelberg, Germany, pp 41-80

22. Meglasson MD, Matschinsky FM (1986) Pancreatic islet glucose metabolism and regulation of insulin secretion. Diab Metab Rev 2: 163-214

23. Matschinsky F, Liang Y, Kesavan P et al. (1993) Glucokinase as pancreatic $\beta$-cell glucose sensor and diabetes gene. J Clin Invest 92: 2092-2098

24. Randle PJ (1993) Glucokinase and candidate genes for type 2 (non-insulin-dependent) diabetes mellitus. Diabetologia 36: 269-275

25. Bell GI, Froguel P, Nishi S et al. (1993) Mutations of the human glucokinase gene and diabetes mellitus. Trends Endocrinol Metab 4: 86-90

26. Bell GI, Pilkis SJ, Weber IT, Polonsky KS (1996) Glucokinase mutations, insulin secretion, and diabetes mellitus. Ann Rev Physiol 58: 171-186

27. Becker TC, Noel RJ, Johnson JH et al. (1996) Differential effects of overexpressed glucokinase and hexokinase $I$ in isolated islets. J Biol Chem 27: 390-394

28. Sturis J, Kurland IJ, Byrne MM et al. (1994) Compensation in pancreatic $\beta$-cell function in subjects with glucokinase mutations. Diabetes 43: 718-723

29. Kraulis PJ (1991) MOLSCRIPT: a program to produce both detailed and schematic plots of protein structures. J Appl Cryst 24: 946-950

30. Charles RS, Harrison RW, Bell GI, Pilkis SJ, Weber IT (1994) Molecular model of human $\beta$-cell glucokinase built by analogy to the crystal structure of yeast hexokinase $B$. Diabetes 43: 718-723 